\title{
Yenilenebilir Enerji Kaynağı Olarak Biyokütle Üretiminin Dünyada ve Türkiye'de Durumu ${ }^{1}$
}

\section{Sitkıcan SARAÇOĞLU ${ }^{2}$}

\section{The Situation of Biomass Production in World and Turkey as a Renewable Energy Resource}

\begin{tabular}{l} 
ARTICLE INFO \\
\hline Article History: \\
Date Submitted: 04.06 .2017 \\
Date Accepted: 11.10.2017 \\
\hline JEL Classification: \\
Q20 \\
Q40 \\
Q42 \\
Keywords: \\
Renewable Energy \\
Biomass \\
Biofuel \\
Bioethanol \\
Biodiesel
\end{tabular}

\begin{abstract}
The energy security and diversification of energy have been the unchangeable elements of energy policies since the oil crisis in 1973. In addition, in 1990s, the negative effects of fossil resources on environment and natural resources have been realized. These factors have created a huge interest about the renewable energy resources. Renewable energy consists of wind, biomass etc. Biomass is described as all organic matters which are renewable in less than 100 years including plants, various products and wastes. This paper aims to evaluate the potential of biomass which is the important one in the renewable energy resources and the biofuel worldwide and in Turkey. Therefore in this paper, primary energy supply and electricity generation from renewable energy sources worldwide and in Turkey, the importance of biomass energy in the renewable energy resources, the current situation of biofuels (bioethanol and biodiesel) worldwide and in Turkey and the policies and practices about the the biofuels worldwide and in Turkey are examined.
\end{abstract}

\footnotetext{
${ }^{1}$ 28-30 Nisan 2015 tarihleri arasında İzmir'de düzenlenen 18. Uluslararası İktisat Öğrencileri Kongresi’nde sunulan bildiri metninin gözden geçirilmiş ve yeniden düzenlenmiş halidir.

${ }^{2}$ Araş. Gör., Gazi Üniversitesi, İktisadi ve İdari Bilimler Fakültesi, İktisat Bölümü, sitkicansaracoglu@gazi.edu.tr
} 


\section{Özet}

1973 yılında yaşanan petrol krizi sonrasında enerji güvenliği ve enerjinin çeşitlendirilmesinin enerji politikalarının değişmez unsurları arasında yer alması ve 1990’lı yıllarda fosil enerji kaynaklarının çevre ve doğal kaynaklar üzerindeki negatif etkilerinin farkına varılması, yenilenebilir enerji kaynaklarına yönelik yoğun bir ilgi yaratmıştır. Yenilenebilir enerji kavramı, rüzgar, biyokütle vb. alt sınıflardan oluşmaktadır. Biyokütle, 100 yıldan daha kısa süre içerisinde yenilenebilen, bitkiler, çeşitli ürünler ve atıkları içeren bütün organik maddeler biçiminde ifade edilmektedir. Bu çalışmanın amacı, yenilenebilir enerji kaynakları arasında önemli bir konumda bulunan biyokütlenin potansiyelini ve biyoyakıtların mevcut durumunu dünya ve Türkiye bağlamında değerlendirmektir. Dolayısıyla bu çalışmada, dünya ve Türkiye bağlamında yenilenebilir enerji kaynakları yoluyla sağlanan birincil enerji arzı ve elektrik üretimi, biyokütle enerjisinin yenilenebilir enerji kaynakları içerisindeki yeri, dünyada ve Türkiye'de biyoyakıtların (biyoetanol ve biyodizel) mevcut durumu ve dünyada ve Türkiye'de biyoyakıtlara ilişkin politikalar ve uygulamalar ele alınacaktır.

Anahtar Kelimeler: Yenilenebilir Enerji, Biyokütle, Biyoyakıt, Biyoetanol, Biyodizel

\section{Giriş}

1973'deki petrol krizi ve 1990'l yıllarda fosil kaynakların olumsuz etkilerinin farkına varılması enerji kaynaklarına yönelik yoğun bir ilginin oluşmasını beraberinde getirmiştir. Özellikle enerjide dışa bağımlılığı azaltmak isteyen ve enerji arzında problemleri olan ülkeler açısından önemli firsatlar yaratan yenilenebilir enerji kaynakları ülkelerin gelişmesinde önemli rol oynamaktadır. Yenilenebilir enerji kavramı, rüzgar, biyokütle vb. alt sinıflardan oluşmaktadır. Biyokütle, 100 yıldan daha kısa süre içerisinde yenilenebilen, bitkiler, çeşitli ürünler ve atıkları içeren bütün organik maddeler biçiminde ifade edilmektedir (Hatunoğlu, 2010:9). Biyokütle taşıdığı büyük potansiyel, çeşitli sosyal ve ekonomik yararlardan dolayı geleceğin yenilenebilir enerji kaynakları arasında önemli bir yer tutmaktadır. Buradan hareketle bu çalışmada, girişi takip eden birinci bölümde dünyada ve Türkiye'de yenilenebilir enerji kaynaklarından sağlanan birincil enerji arzına ve elektrik üretimine yer verilecektir. İkinci bölümde, biyokütle enerjisinin yenilenebilir enerji kaynakları içerisindeki yeri ele alınacaktır. 
Üçüncü bölümde, dünyada ve Türkiye'de biyoyakıtların (biyoetanol ve biyodizel) mevcut durumuna değinilecektir. Çalışmanın dördüncü bölümünde ise dünyada ve Türkiye'de biyoyakıtlara ilişkin politikalar ve uygulamalara değinilecektir. Sonuç bölümü ise genel bir değerlendirme için ayrılmıştır.

\section{Yenilenebilir Enerji Kaynaklarından Elde Edilen Birincil Enerji Arzı ve} Elektrik Üretimi: Dünya ve Türkiye

Bu bölümde, farklı yenilenebilir enerji kaynaklarından elde edilen toplam birincil enerji arzı ve elektrik üretimi, kıtalar ve lider ülkeler çerçevesinde ele alınacaktır. Diğer taraftan, çalışmada sıklıkla kullanılan teknik kavramların açıklamasına yer vermek yerinde olacaktır. Toplam birincil enerji arzı ölçüm birimi olan Eksajul, $10^{18}$ Jul'e eşittir. Elektrik üretimi ölçüm birimi olan Terawatt/saat ise $10^{12}$ watt/saat'e eşittir.

Tablo 1: Yenilenebilir Kaynaklardan Elde Edilen Toplam Birincil Enerji Arzı (Eksajul cinsinden)

\begin{tabular}{|c|c|c|c|c|c|c|c|}
\hline & Toplam & Biyokütle & Hidroelektrik & Rüzgar & Güneş & Jeotermal & Dalga, gel-git \\
\hline 2000 & 54,9 & 42,9 & 9,43 & 0,11 & 0,21 & 2,19 & 0,002 \\
\hline 2005 & 60,7 & 47,2 & 10,6 & 0,37 & 0,31 & 2,25 & 0,002 \\
\hline 2010 & 71,0 & 53,9 & 12,4 & 1,23 & 0,76 & 2,70 & 0,002 \\
\hline 2011 & 72,8 & 54,9 & 12,6 & 1,57 & 1,01 & 2,76 & 0,002 \\
\hline 2012 & 75,3 & 56,1 & 13,2 & 1,88 & 1,28 & 2,78 & 0,002 \\
\hline 2013 & 78,1 & 57,7 & 13,6 & 2,29 & 1,69 & 2,77 & 0,003 \\
\hline
\end{tabular}

Kaynak: WBA (2016: 19).

Tablo 1'e göre yenilenebilir kaynaklardan elde edilen toplam birincil enerji arzı 20002013 döneminde \%42,25 oranında artış göstererek, 2000'deki 54,9 Eksajul düzeyinden 2013'de 78,1 Eksajul düzeyine ulaşmıştır. Biyokütleden elde edilen toplam birincil enerji arzı 20002013 döneminde \%34,50 oranında artış göstererek, 2000'deki 42,9 Eksajul düzeyinden 2013'de 57,7 Eksajul düzeyine ulaşmıştır. Diğer taraftan hidroelektrik, rüzgar, güneş, jeotermal, dalga, gel-git enerjisinden elde edilen toplam birincil enerji arzı 2000-2013 döneminde sırasıyla, \%44,22, \%1981, \%704, \%26,48 ve \%50 oranında artış göstermiştir. 
Tablo 2: Kıtalara göre Yenilenebilir Kaynaklardan Elde Edilen Toplam Birincil Enerji Arzı (Eksajul cinsinden, 2013 yılı)

\begin{tabular}{|l|c|c|c|c|c|c|c|}
\hline & Toplam & Biyokütle & Hidroelektrik & Rüzgar & Güneş & Jeotermal & Dalga, gel-git \\
\hline Afrika & 15,5 & 15,0 & 0,42 & 0,01 & 0,01 & 0,07 & 0,000 \\
\hline Amerika & 16,9 & 10,4 & 5,01 & 0,70 & 0,16 & 0,64 & 0,000 \\
\hline Asya & 33,7 & 25,5 & 5,06 & 0,69 & 1,04 & 1,43 & 0,002 \\
\hline Avrupa & 11,4 & 6,61 & 3,01 & 0,86 & 0,46 & 0,46 & 0,002 \\
\hline Okyanusya & 0,65 & 0,26 & 0,15 & 0,03 & 0,02 & 0,18 & 0,000 \\
\hline Dünya & 78,1 & 57,7 & 13,6 & 2,29 & 1,69 & 2,77 & 0,003 \\
\hline
\end{tabular}

Kaynak: WBA (2016: 19).

Tablo 2'ye göre 2013 yılı verileri ışı̆̆ında, yenilenebilir kaynaklardan elde edilen toplam birincil enerji arzının \%43,15'lik kısmı Asya tarafından karşılanırken, Asya'yı sırasıyla \%21,63'lük oranla Amerika, \%19,85 oranla Afrika, \%15,00'lik oranla Avrupa ve \%0,80'lik oranla Okyanusya takip etmektedir. Asya, bunun yanı sıra rüzgar dışında diğer yenilenebilir kaynaklardan elde edilen toplam birincil enerji arzı bağlamında lider konumdadır. Rüzgardan elde edilen toplam birincil enerji arzı açısından ise \%37,55'lik kısmını karşılayan Avrupa lider konumdadır.

Tablo 3: Yenilenebilir Kaynaklardan Elde Edilen Toplam Birincil Enerji Arzı (Lider 10 ülke, Eksajul cinsinden, 2013 yılı)

\begin{tabular}{|l|l|r|r|r|r|r|r|r|}
\hline \multicolumn{2}{|l|}{ Ülke } & Toplam & Biyokütle & Hidroelektrik & Rüzgar & Güneş & Jeotermal & Dalga, gel-git \\
\hline 1 & Çin & 13,8 & 9,03 & 3,28 & 0,51 & 0,84 & 0,19 & 0,00 \\
\hline 2 & Hindistan & 8,55 & 7,89 & 0,51 & 0,12 & 0,03 & 0,00 & 0,00 \\
\hline 3 & ABD & 6,15 & 4,08 & 0,98 & 0,61 & 0,12 & 0,36 & 0,00 \\
\hline 4 & Brezilya & 4,86 & 3,40 & 1,41 & 0,02 & 0,02 & 0,00 & 0,00 \\
\hline 5 & Nijerya & 4,58 & 4,56 & 0,02 & 0,00 & 0,00 & 0,00 & 0,00 \\
\hline 6 & Endonezya & 3,04 & 2,30 & 0,06 & 0,00 & 0,00 & 0,68 & 0,00 \\
\hline 7 & Kanada & 2,01 & 0,55 & 1,41 & 0,04 & 0,00 & 0,00 & 0,00 \\
\hline 8 & Etiyopya & 1,90 & 1,87 & 0,03 & 0,00 & 0,00 & 0,00 & 0,00 \\
\hline 9 & Pakistan & 1,38 & 1,27 & 0,11 & 0,00 & 0,00 & 0,00 & 0,00 \\
\hline 10 & Tayland & 1,06 & 1,03 & 0,02 & 0,00 & 0,00 & 0,00 & 0,00 \\
\hline $\begin{array}{l}\text { Toplam (Lider 10 } \\
\text { ülke) }\end{array}$ & 47,40 & 36,0 & 7,82 & 1,31 & 1,03 & 1,23 & 0,00 \\
\hline
\end{tabular}




\begin{tabular}{|l|r|r|r|r|r|r|r|}
\hline AB-28 & 8,74 & 5,87 & 1,33 & 0,85 & 0,44 & 0,25 & 0,00 \\
\hline Dünya & 78,10 & 57,7 & 13,6 & 2,29 & 1,69 & 2,77 & 0,00 \\
\hline
\end{tabular}

Kaynak: WBA (2016: 20).

Tablo 3'e göre 2013 yılı verileri 1şı̆̆ında lider 10 ülke, yenilenebilir kaynaklardan elde edilen dünya toplam birincil enerji arzının \%60,70’lık kısmını karşılamaktadır. Lider Çin’i sirasiyla Hindistan, ABD, Brezilya, Nijerya, Endonezya, Kanada, Etiyopya, Pakistan ve Tayland takip etmektedir. Çin, biyokütle, hidroelektrik ve güneşten elde edilen toplam birincil enerji arzı bağlamında; ABD rüzgardan elde edilen toplam birincil enerji arzı bağlamında ve Endonezya jeotermalden elde edilen toplam birincil enerji arzı bağlamında lider konumdadır.

Tablo 4: Yenilenebilir Kaynaklardan Elde Edilen Elektrik Üretimi (Terawatt/saat cinsinden)

\begin{tabular}{|c|c|c|c|c|c|c|c|c|}
\hline & Toplam & $\begin{array}{l}\text { Toplam } \\
\text { Yenilenebilir } \\
\text { Enerji }\end{array}$ & Biyokütle & Hidroelektrik & Rüzgar & Güneş & Jeotermal & $\begin{array}{l}\text { Dalga, } \\
\text { gel-git }\end{array}$ \\
\hline 2000 & 15505 & 2954 & 170 & 2699 & 31,4 & 1,56 & 52,0 & 0,55 \\
\hline 2005 & 18367 & 3421 & 237 & 3017 & 104 & 4,64 & 58,3 & 0,52 \\
\hline 2010 & 21549 & 4354 & 380 & 3530 & 341 & 33,95 & 68,1 & 0,51 \\
\hline 2011 & 22244 & 4572 & 409 & 3592 & 435 & 66,06 & 69,3 & 0,51 \\
\hline 2012 & 22740 & 4885 & 435 & 3753 & 523 & 103,47 & 70,2 & 0,50 \\
\hline 2013 & 23406 & 5190 & 462 & 3874 & 637 & 144,46 & 71,6 & 0,93 \\
\hline
\end{tabular}

Kaynak: WBA (2016: 20).

Tablo 4'e göre yenilenebilir kaynaklardan elde edilen elektrik üretimi 2000-2013 döneminde \%75,70 oranında artış göstererek 2000'deki 2954 Terawatt/saat düzeyinden 2013 'de 5190 Terawatt/saat düzeyine ulaşmıştır. Biyokütleden elde edilen elektrik üretimi 2000-2013 döneminde \%171,80 oranında artış göstererek 2000'deki 170 Terawatt/saatten 2013'de 462 Terawatt/saat düzeyine ulaşmıştır. Diğer taraftan hidroelektrik, rüzgar, güneş, jeotermal, dalga, gel-gitten elde edilen elektrik üretimi 2000-2013 döneminde sirasıyla, \%43,53, \%1928,66, \%9160, 25, \%37,70 ve \%69,09 oranında artış göstermiştir.

Tablo 5: Kıtalara göre Yenilenebilir Kaynaklardan Elde Edilen Elektrik Üretimi (Terawatt/saat cinsinden, 2013 yılı) 


\begin{tabular}{|l|r|r|r|r|r|r|r|r|}
\hline & Toplam & $\begin{array}{l}\text { Toplam } \\
\text { Yenilenebilir } \\
\text { Enerji }\end{array}$ & Biyokütle & Hidroelektrik & Rüzgar & Güneş & Jeotermal & $\begin{array}{l}\text { Dalga, } \\
\text { gel-git }\end{array}$ \\
\hline Afrika & 735 & 127 & 1,27 & 119 & 3,62 & 0,53 & 2,02 & 0,00 \\
\hline Amerika & 6511 & 1795 & 142 & 1412 & 195 & 16,54 & 28,5 & 0,02 \\
\hline Asya & 10772 & 1812 & 131 & 1429 & 191 & 37,23 & 23,1 & 0,49 \\
\hline Avrupa & 5095 & 1393 & 185 & 872 & 238 & 86,40 & 11,6 & 0,42 \\
\hline Okyanusya & 292 & 63,5 & 2,58 & 41,3 & 9,35 & 3,82 & 6,42 & 0,00 \\
\hline Dünya & 23406 & 5190 & 462 & 3874 & 637 & 144,46 & 71,6 & 0,93 \\
\hline
\end{tabular}

Kaynak: WBA (2016: 21).

Tablo 5'e göre 2013 yılı verileri 1şı̆̆ında,yenilenebilir kaynaklardan elde edilen elektrik üretiminin \%34,91'lik kısmı Asya tarafından karşılanırken, Asya'yı sırasıyla \%34,58'lik oranla Amerika, \%26,84'lük oranla Avrupa, \%2,44'lük oranla Afrika ve \%1,22'lik oranla Okyanusya takip etmektedir. Biyokütleden, rüzgardan ve güneşten elde edilen elektrik üretiminde Avrupa; hidroelektrikten ve dalga, gel-gitten elde edilen elektrik üretiminde Asya ve jeotermalden elde edilen elektrik üretiminde Amerika lider konumdadır.

Tablo 6: Yenilenebilir Kaynaklardan Elde Edilen Elektrik Üretimi (Lider 10 ülke, Terawatt/saat cinsinden, 2013 yılı)

\begin{tabular}{|c|c|c|c|c|c|c|c|c|c|}
\hline \multicolumn{2}{|c|}{ Ülke } & \multirow{2}{*}{$\begin{array}{l}\text { Topla } \\
\text { m } \\
5447\end{array}$} & \multirow{2}{*}{$\begin{array}{l}\text { Toplam } \\
\text { Yenilenebili } \\
\text { r Enerji } \\
1128\end{array}$} & \multirow{2}{*}{$\begin{array}{l}\begin{array}{l}\text { Biyokütl } \\
\text { e }\end{array} \\
50,6\end{array}$} & \multirow{2}{*}{$\begin{array}{l}\text { Hidroelektri } \\
\mathrm{k} \\
920\end{array}$} & \multirow{2}{*}{$\begin{array}{l}\begin{array}{l}\text { Rüzga } \\
\text { r }\end{array} \\
141\end{array}$} & \multirow{2}{*}{$\begin{array}{l}\text { Güneş } \\
15,53\end{array}$} & \multirow{2}{*}{$\begin{array}{l}\text { Jeoterma } \\
\begin{array}{r}1 \\
0,11\end{array}\end{array}$} & \multirow{2}{*}{$\begin{array}{l}\begin{array}{c}\text { Dalga } \\
\text { gel- } \\
\text { git }\end{array} \\
\qquad 0,01\end{array}$} \\
\hline 1 & Çin & & & & & & & & \\
\hline 2 & $\mathrm{ABD}$ & 4306 & 572 & 78,2 & 290 & 170 & 15,61 & 18,4 & 0,00 \\
\hline 3 & Brezilya & 570 & 438 & 40,4 & 391 & 6,58 & 0,00 & 0,00 & 0,00 \\
\hline 4 & Kanada & 652 & 409 & 5,45 & 392 & 11,6 & 0,36 & 0,00 & 0,02 \\
\hline 5 & Hindistan & 1193 & 202 & 23,1 & 142 & 33,6 & 3,43 & 0,00 & 0,00 \\
\hline 6 & Rusya & 1059 & 186 & 2,93 & 183 & 0,01 & 0,00 & 0,44 & 0,00 \\
\hline 7 & Japonya & 1045 & 148 & 40,7 & 84,9 & 5,20 & 14,3 & 2,60 & 0,00 \\
\hline 8 & Norveç & 134 & 131 & 0,55 & 129 & 1,89 & 0,00 & 0,00 & 0,00 \\
\hline 9 & $\begin{array}{l}\text { Venezuel } \\
\text { a }\end{array}$ & 123 & 83,5 & 0,00 & 83,5 & 0,00 & 0,00 & 0,00 & 0,00 \\
\hline 0 & Türkiye & 240 & 69,3 & 0,98 & 59,4 & 7,56 & 0,00 & 1,36 & 0,00 \\
\hline \multicolumn{2}{|c|}{$\begin{array}{l}\text { Toplam (Lider } \\
10 \text { ülke) }\end{array}$} & 14771 & 3367 & 243 & 2674 & 377 & 49,24 & 22,90 & 0,02 \\
\hline
\end{tabular}




\begin{tabular}{|l|r|r|r|r|r|r|r|r|}
\hline AB-28 & 3262 & 907 & 178 & 402 & 235 & 85,30 & 5,94 & 0,42 \\
\hline Dünya & 23406 & 5190 & 462 & 3874 & 637 & 144,4 & 71,60 & 0,93 \\
\hline
\end{tabular}

Kaynak: WBA (2016: 22).

Tablo 6'ya göre 2013 yılı verileri 1şı̆̆ında lider 10 ülke, yenilenebilir kaynaklardan elde edilen elektrik üretiminin \%64,87'lik kısmını karşılamaktadır. Lider Çin'i sırasıyla ABD, Brezilya, Kanada, Hindistan, Rusya, Japonya, Norveç, Venezuela ve Türkiye takip etmektedir. $\mathrm{ABD}$, biyokütle, rüzgar, güneş ve jeotermalden elde edilen elektrik üretimi bağlamında; Çin hidroelektrikten elde edilen elektrik üretimi bağlamında ve Kanada dalga, gel-gitten elde edilen elektrik üretimi bağlamında lider konumdadır.

Şekil 1: Türkiye'de yenilenebilir enerjiden üretilen elektrik enerjisinin düzeyi (2001-2012; Terawatt/saat cinsinden)

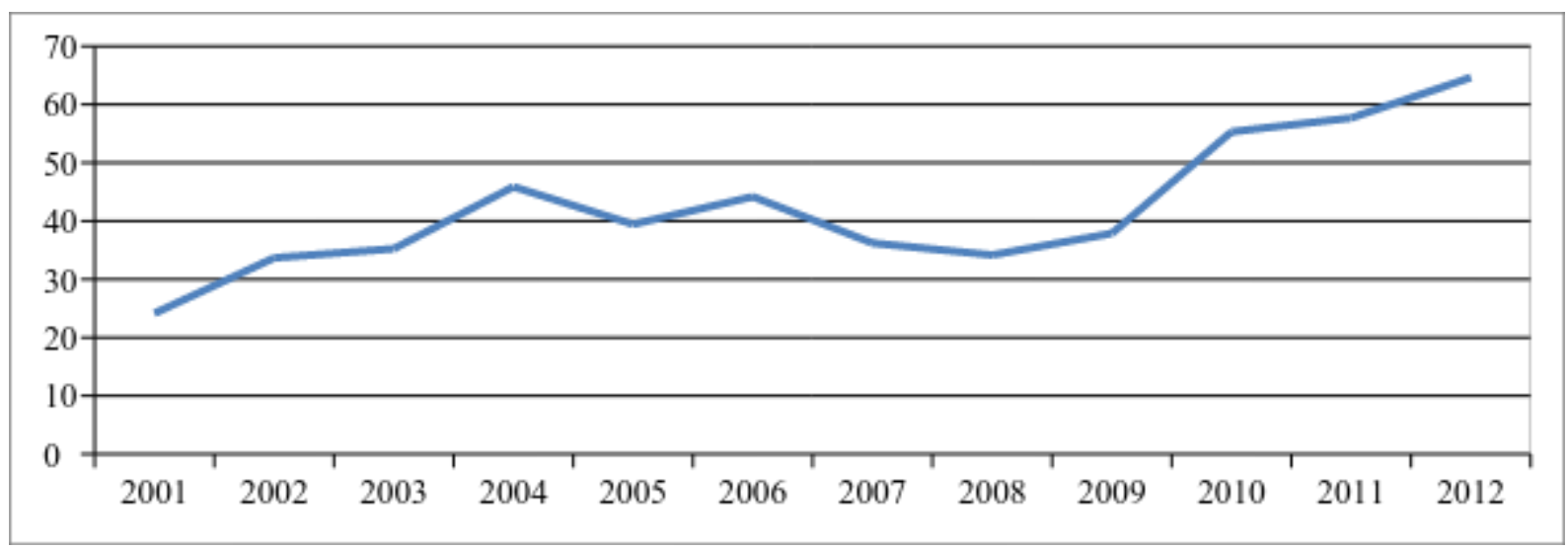

Kaynak: EIA (2017).

Şekil 1'e göre, Türkiye'de yenilenebilir enerjiden üretilen elektrik enerjisi, 2001-2012 yıllarında dalgalı bir yapı göstermiştir. Türkiye'de yenilenebilir enerjiden üretilen elektrik enerjisi, 2001 'deki 24,152 Terawatt/saat düzeyinden 2004'de 45,878 Terawatt/saat düzeyine ulaşmış olup 2004'den sonra genel itibariyle düşüş göstererek 2008'de 34,165 Terawatt/saat düzeyinde gerçekleşmiştir. 2008-2012 döneminde tekrar yükseliş gösteren yenilenebilir enerjiden üretilen elektrik enerjisi 2012'de 64,367 Terawatt/saat düzeyine ulaşmıştır. 
Şekil 2: Türkiye'deki farklı yenilenebilir kaynakların yenilenebilir enerjiden üretilen elektrik enerjisi içerisindeki payları (2001-2012)

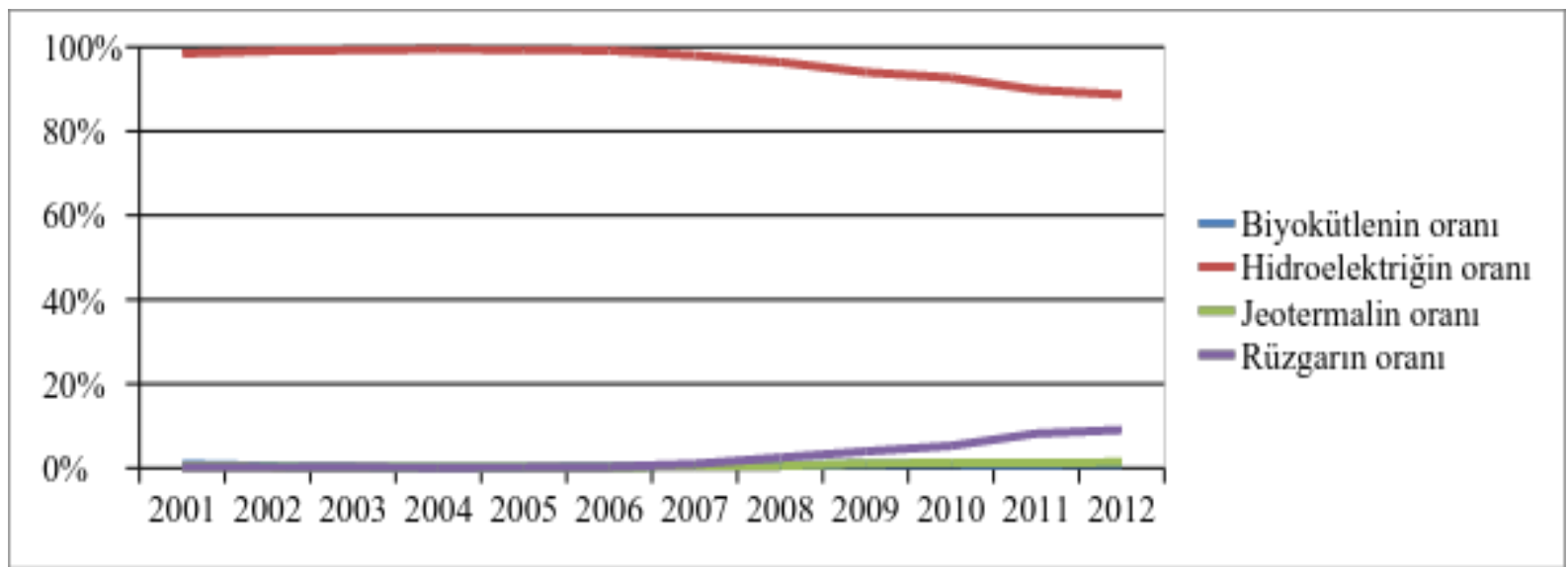

Kaynak: EIA (2017).

Şekil 2'ye göre, Türkiye'deki farklı yenilenebilir kaynakların yenilebilir enerjiden üretilen elektrik enerjisi içerisindeki payları açısından 2001-2012 döneminde hidroelektrik en büyük paya sahiptir. Özellikle 2001-2006 döneminde hidroelektriğin pay1 \%99 seviyesindedir. Bu dönemde diğer yenilenebilir enerji kaynaklarının payı \%0,01 ile \%0,03 arasındadır. Ancak 2006 sonrasında hidroelektriğin payı düşmeye diğer yenilenebilir kaynakların özellikle rüzgar ve jeotermalin payı ise artmaya başlamıştır. Hidroelektriğin payı 2012'de \%88,6 ya düşerken rüzgarın payı \%9,1'e ve jeotermalin payı ise $\% 1,4$ e yükselmiştir.

\section{Biyokütle Enerjisinin Yenilenebilir Enerji Kaynakları İçerisindeki Yeri}

Çevreyi koruyan, kirletmeyen ve oldukça güncel olan enerji kaynaklarından biri olan biyokütle enerjisini; tarımsal ürünlerden çeşitli yöntemler yoluyla üretilen, ticari ve birtakım standart özellikler taşıyan katı, sıvı ve gaz durumundaki bitkisel enerji kaynakları biçiminde ifade etmek mümkündür (Öztürk ve Ekinci, 2016: 18 ve Horuz vd., 2015: 69). Biyokütle enerji kaynaklarını, klasik biyokütle enerji kaynakları ve modern biyokütle enerji kaynakları biçiminde iki gruba ayırmak mümkündür. Biyokütle enerjisinin "klasik" kaynakları arasında odun ve tezek; "modern" kaynakları arasında ise biyogaz, biyoetanol, biyodizel vb. enerji kaynakları yer almaktadır (Akdoğan ve Emeklier, 2007: 34 ve Yılmaz, 2012: 46).Biyokütle enerjisinin avantajlarını aşağıdaki biçimde sıralamak mümkündür (BAKA, 2012: 7):

- Birçok yerde üretilebilmesi 
- Üretim ve çevrim teknolojilerine ilişkin yüksek bilgi düzeyi

- Her ölçekte enerji üretimine imkan vermesi

- Düşük düzeydeki 1şık şiddetlerinin yeterli olması

- Depolanabilme özelliğine sahip olması

- $5-35^{\circ} \mathrm{C}$ arasındaki sıcaklıkların yeterli olması

- Sosyoekonomik gelişmeler üzerinde önemli etkiler yaratması

- Çevre kirliliğine neden olmaması

- Diğer enerji kaynaklarına görece daha az sera etkisine neden olması

- Atmosferde $\mathrm{CO}_{2}$ dengesinin sağlanması

- Asit yağmurlarına neden olmaması

Tablo 7: Kıtalara göre Biyokütleden Elde Edilen Toplam Birincil Enerji Arzı(Eksajul cinsinden)

\begin{tabular}{|c|c|c|c|c|c|c|}
\hline & Dünya & Afrika & Amerika & Asya & Avrupa & Okyanusya \\
\hline 2000 & 42,90 & 10,40 & 7,30 & 21,60 & 3,33 & 0,26 \\
\hline 2005 & 47,20 & 11,90 & 8,21 & 22,60 & 4,20 & 0,27 \\
\hline 2010 & 53,90 & 13,70 & 9,67 & 24,30 & 5,96 & 0,22 \\
\hline 2011 & 54,90 & 14,30 & 9,70 & 24,70 & 6,01 & 0,22 \\
\hline 2012 & 56,10 & 14,60 & 9,69 & 25,00 & 6,48 & 0,26 \\
\hline 2013 & 57,70 & 15,00 & 10,40 & 25,50 & 6,61 & 0,26 \\
\hline
\end{tabular}

Kaynak: WBA (2016: 29).

Tablo 7’ye göre biyokütleden elde edilen dünya toplam birincil enerji arzı 2000-2013 döneminde \%34,50 oranında artış göstererek 2000'deki 42,90 Eksajul düzeyinden 2013'de 57,70 Eksajul düzeyine ulaşmıştır. 2000-20013 döneminde biyokütleden elde edilen toplam birincil enerji arzı, Afrika'da \%44,23 oranında, Amerika'da \%42,47 oranında, Asya' da \%18,05 oranında, Avrupa'da \%98,50 oranında artış gösterirken ve Okyanusya'da dalgalanmalar yaşayarak dönem başındaki düzeyinde seyretmiş̧tir. 2013 yılı verilerine göre biyokütleden elde edilen dünya toplam birincil enerji arzının \%44,19’luk kısmını karşılayan Asya lider olmakla birlikte, Asya'yı sırasıyla \%26,00’lık kısmını karşılayan Afrika, \%18,02'lik kısmını karşılayan Amerika, \%11,45'lik kısmını karşılayan Avrupa ve \%0,45'lik kısmını karşılayan Okyanusya takip etmektedir. 2013 y1lı verilerine göre biyokütleden elde edilen toplam birincil enerji arzı 
bağlamında lider Çin'i sırasıyla Hindistan, Nijerya, ABD, Brezilya, Endonezya, Etiyopya, Pakistan, Tayland ve Tanzanya takip etmektedir(WBA, 2016: 30).

Tablo 8: Kıtalara göre Biyokütleden Elde Edilen Elektrik Üretimi (Terawatt/saat cinsinden)

\begin{tabular}{|l|r|r|r|r|r|c|}
\hline & Dünya & Afrika & Amerika & \multicolumn{1}{l|}{ Asya } & Avrupa & Okyanusya \\
\hline 2000 & 170 & 1,08 & 93,90 & 22,20 & 50,80 & 1,72 \\
\hline 2005 & 237 & 1,31 & 103 & 38,60 & 89,40 & 4,33 \\
\hline 2010 & 380 & 1,70 & 131 & 95,60 & 149 & 3,38 \\
\hline 2011 & 409 & 1,31 & 136 & 109 & 159 & 2,73 \\
\hline 2012 & 435 & 1,26 & 138 & 116 & 176 & 2,97 \\
\hline 2013 & 462 & 1,27 & 142 & 130 & 185 & 2,58 \\
\hline
\end{tabular}

Kaynak: WBA (2016: 43).

Tablo 8'e göre biyokütleden elde edilen dünya elektrik üretimi 2000-2013 döneminde \%171,76 oranında artış göstererek 2000'deki 170 Terawatt/saat düzeyinden 2013'de 462 Terawatt/saat düzeyine ulaşmıştır. 2000-20013 döneminde biyokütleden elde edilen elektrik üretimi, Afrika'da \%17,59 oranında, Amerika'da \%51,22 oranında, Asya'da \%485,58 oranında, Avrupa'da \%264,17 oranında ve Okyanusya'da \%50 oranında artış göstermiştir.2013 yılı verilerine göre biyokütledenelde edilen elektrik üretiminde Avrupa lider olmakla birlikte, Avrupa'yı sırasıyla Amerika, Asya, Okyanusya ve Afrika takip etmektedir. 2013 yılı verilerine göre biyokütleden elde edilen elektrik üretimi bağlamında lider ABD’yi sırasıyla, Çin, Japonya, Brezilya, Hindistan, Tayland, Şili, Kanada, Rusya ve İsviçre takip etmektedir (WBA, 2016: 44).

\section{Biyoyakıtların Mevcut Durumu: Dünya ve Türkiye}

Biyoyakıtlar iki ayrı grupta ele alınırken biyoyakıtların çok büyük bir kısmını işaret eden "birinci nesil biyoyakıtlar", tarımsal üretimle elde edilen ve gıda nitelğindeki bitkisel ürünlerin hammadde olarak kullanıldığı biyoyakıtlardır. "İkinci nesil biyoyakıtlar" ise tarım ve ormancılık atıklarının hammadde olarak kullanıldığı biyoyakıtlardır (Hatunoğlu, 2010: 11). Biyoyakıtların yakılmasının, atmosferindeki karbondioksit düzeyini artırmaması nedeniyle, 
atmosferdeki karbondioksit miktarının artışını önleyebilmek amacıyla fosil yakıtlar yerine biyoyakıtların tercih edilmesi gerektiği yaygın olarak kabul edilmektedir (Narin, 2008: 2).

Tablo 9: Kıtalara göre BiyoyakıtÜretimi (Milyar Litre cinsinden)

\begin{tabular}{|c|c|c|c|c|c|c|}
\hline & Dünya & Afrika & Amerika & Asya & Avrupa & Okyanusya \\
\hline 2000 & 18,00 & 0,00 & 16,90 & 0,14 & 0,95 & 0,00 \\
\hline 2005 & 38,70 & 0,00 & 32,30 & 1,64 & 4,73 & 0,04 \\
\hline 2010 & 105,00 & 0,01 & 83,00 & 5,39 & 16,7 & 0,35 \\
\hline 2011 & 106,00 & 0,01 & 83,90 & 6,99 & 15,1 & 0,43 \\
\hline 2012 & 108,00 & 0,01 & 82,30 & 8,38 & 16,4 & 0,40 \\
\hline 2013 & 118,00 & 0,01 & 89,80 & 9,36 & 18,2 & 0,38 \\
\hline
\end{tabular}

Kaynak: WBA (2016: 51).

Tablo 9'a göre dünya biyoyakıt üretimi 2000-2013 döneminde \%555,55 oranında artı̧̧ göstererek 2000'deki 18 Milyar Litre düzeyinden 2013'de 118 Milyar Litre düzeyine ulaşmıştır. 2000-20013 döneminde biyokütle üretimi, Amerika'da \%431,36 oranında, Asya'da \%6585, 71 oranında ve Avrupa'da \%1815,79 oranında artış göstermiştir. Afrika ve Okyanusya'da ise dönem başında biyoyakıt üretimi söz konusu değil iken sonraki yıllarda biyoyakıt üretilmeye başlanmıştır. 2013 yılı verilerine göre biyoyakıt üretiminde Amerika lider olmakla birlikte, Amerika’yı sırasıyla Avrupa, Asya, Okyanusya ve Afrika takip etmektedir.

\section{Şekil 3: Türkiye'nin Toplam Biyoyakıt Üretimi (Günlük Bin Varil Cinsinden)}

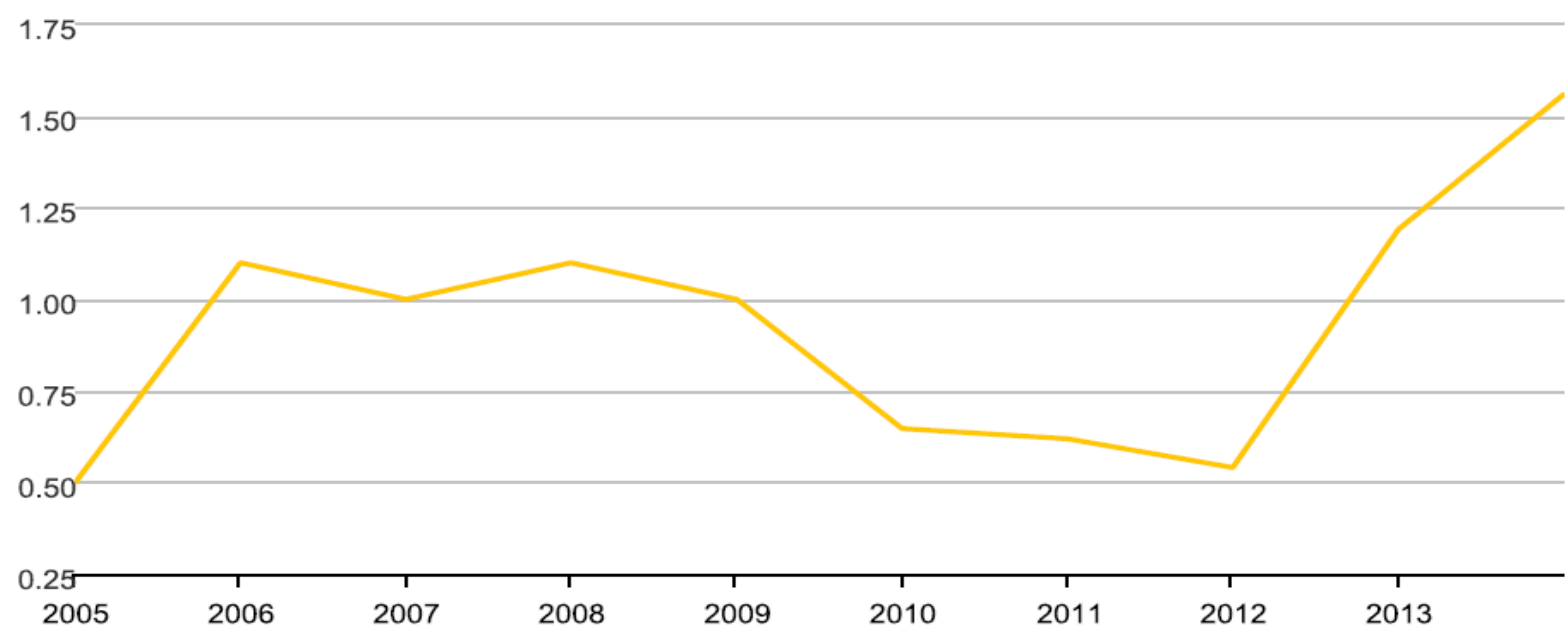

Kaynak: EIA (2017). 
Şekil 3'e göre Türkiye'nin biyoyakıt üretim düzeyi 2005-2013 döneminde dalgalı bir seyir izlemiştir. 2005'deki günlük 0,5 bin varil düzeyinden 2006 'da günlük 1,1 bin varil düzeyine yükselmiştir. 2006-2007 döneminde biyoyakıt üretiminde gerileme yaşanırken 20072008 döneminde biyoyakıt üretiminde artış yaşanmış, sonrasında ise biyoyakıt üretiminde yeniden gerileme yaşanmış ve 2008-2012 döneminde biyoyakıt üretimi günlük 1,1 bin varil düzeyinden günlük 0,54 bin varil düzeyine gerilemiştir. Türkiye'nin biyoyakıt üretimi 2012 sonrasında yeniden yükseliş trendine girmiştir.

Tablo 10: Farklı türlere göre dünyada toplam Biyoyakıt Üretimi (Milyar Litre cinsinden)

\begin{tabular}{|c|c|c|c|c|}
\hline & Toplam Biyoyakı Üretimi & Biyoetanol & Biyodizel & Diğer biyoyakıtlar \\
\hline 2000 & 18,00 & 13,20 & 0,84 & 3,94 \\
\hline 2005 & 38,70 & 26,90 & 3,67 & 8,14 \\
\hline 2010 & 105 & 65,40 & 20,20 & 19,80 \\
\hline 2011 & 106 & 69,20 & 23,30 & 13,80 \\
\hline 2012 & 108 & 68,40 & 25,30 & 13,80 \\
\hline 2013 & 118 & 73,50 & 28,90 & 15,40 \\
\hline
\end{tabular}

Kaynak: WBA (2016: 52).

Tablo 10'a göre dünya toplam biyoyakıt üretimi 2000-2013 döneminde \%555,55 oranında artış göstererek 2000'deki 18 Milyar Litre düzeyinden 2013'de 118 Milyar Litre düzeyine ulaşmıştır. 2013 yılı verilerine göre, dünya toplam biyoyakıt üretiminin \%62,28'lik kısmı biyoetanolden, \%24,49'luk kısmı biyodizelden ve \%13,05'lik kısmı diğer biyoyakıtlardan oluşmaktadır. Dünya biyoetanol üretimi 2000-2013 döneminde \%456,81 oranında artış göstererek 2000'deki 13,20 Milyar Litre düzeyinden 2013'de 73,50 Milyar Litre düzeyine ulaşmıştır. Dünya biyodizel üretimi 2000-2013 döneminde \%3340,47 oranında artış göstererek 2000'deki 0,84 Milyar Litre düzeyinden 2013'de 28,90 Milyar Litre düzeyine ulaşmıştır. Dünya diğer biyoyakıtlar üretimi ise 2000-2013 döneminde \%290,86 oranında artış göstererek 2000'deki 3,94 Milyar Litre düzeyinden 2013'de 15,40 Milyar Litre düzeyine ulaşmıştır. 
Tablo 11: Farklı türlere ve kıtalara göre Biyoyakıt Üretimi (Milyar Litre cinsinden, 2003 yilı)

\begin{tabular}{|l|c|c|c|c|}
\hline & Toplam Biyoyakıt Üretimi & Biyoetanol & Biyodizel & Diğer biyoyakitlar \\
\hline Afrika & 0,01 & 0,01 & 0,00 & 0,00 \\
\hline Amerika & 89,80 & 64,00 & 11,00 & 14,80 \\
\hline Asya & 9,36 & 4,07 & 5,22 & 0,07 \\
\hline Avrupa & 18,20 & 5,11 & 12,50 & 0,60 \\
\hline Okyanusya & 0,38 & 0,29 & 0,09 & 0,00 \\
\hline Dünya & 118 & 73,50 & 28,90 & 15,40 \\
\hline
\end{tabular}

Kaynak: WBA (2016: 52).

Tablo 11'e göre 2013 yılı verileri 1şığında biyoyakıt üretiminde Amerika lider olmakla birlikte, Amerika'yı sırasıyla Avrupa, Asya, Okyanusya ve Afrika takip etmektedir. Biyoetanol ve diğer biyoyakıtlar üretiminde Amerika, biyodizel üretiminde ise Avrupa lider konumdadır.

Biyoetanol, kimyasal bileşiminde nişasta, şeker veya selüloz içeren bitkilerin üretim sürecinde hammadde olarak kullanıldığı ve ulaşım araçlarında yakıt amacıyla kullanılabilen bir biyoyakıt türüdür. Dünyada biyoetanol üretiminde kullanılan hammaddeler arazi ve iklim şartlarına bağlı olarak değişse de şeker kamışı ve mısır dünyada en çok kullanılan biyoetanol hammaddeleridir (Hatunoğlu, 2010: 13). Avrupa'da buğday ve şeker pancarı, ABD’de mısır ve Brezilya'da şeker kamışı biyoetanol üretiminde kullanılan hammaddelerdir (Dağdelen, 2015: 11). Biyoetanol, hava kirliliğinin azaltılması veya petrol ürünlerinin tüketiminin azaltılması amacıyla, benzinle farklı oranlarda karıştırılarak kullanılabilmektedir (Sabancı vd., 2010: 8). Biyoetanol türlerini, benzinle karışım oranlarına göre E2, E5, E10 ve E85 olarak adlandırmak mümkündür (Narin, 2008: 4-5).

Tablo 12: Kıtalara göre Biyoetanol Üretimi (Milyar Litre cinsinden)

\begin{tabular}{|l|c|c|c|c|c|c|}
\hline & Dünya & Afrika & Amerika & Asya & Avrupa & Okyanusya \\
\hline 2000 & 13,20 & 0,00 & 13,00 & 0,14 & 0,12 & 0,00 \\
\hline 2005 & 26,90 & 0,00 & 24,30 & 1,56 & 0,94 & 0,04 \\
\hline 2010 & 65,40 & 0,01 & 58,50 & 2,82 & 3,85 & 0,28 \\
\hline 2011 & 69,20 & 0,01 & 62,00 & 3,43 & 3,44 & 0,32 \\
\hline 2012 & 68,40 & 0,01 & 60,40 & 3,71 & 4,00 & 0,31 \\
\hline 2013 & 73,50 & 0,01 & 64,00 & 4,07 & 5,11 & 0,29 \\
\hline
\end{tabular}


Kaynak: WBA (2016: 53).

Tablo 12’ye göre dünya biyoetanol üretimi 2000-2013 döneminde $\% 456,81$ oranında artış göstererek 2000'deki 13,20 Milyar Litre düzeyinden 2013'de 73,50 Milyar Litre düzeyine ulaşmıştır. 2000-20013 döneminde biyoetanol üretimi, Amerika'da \%392,30 oranında, Asya'da \%2807,14 oranında ve Avrupa'da \%4158,33 oranında artış göstermiştir. Afrika ve Okyanusya'da ise dönem başında biyoetanol üretimi söz konusu değil iken sonraki yıllarda biyoetanol üretilmeye başlanmıştır. 2013 yılı verilerine göre biyoetanol üretiminde Amerika lider olmakla birlikte, Amerika'yı sirasiyla Avrupa, Asya, Okyanusya ve Afrika takip etmektedir. 2015 yılı verilerine göre biyoetanol üretimi bağlamında lider ABD’yi sırasıyla, Brezilya, Çin, Kanada, Tayland, Almanya, Fransa, Arjantin, Hindistan ve Belçika takip etmektedir (WBA, 2016: 53).

\section{Şekil 4: Türkiye'nin Biyoetanol üretimi (Günlük Bin Varil Cinsinden)}

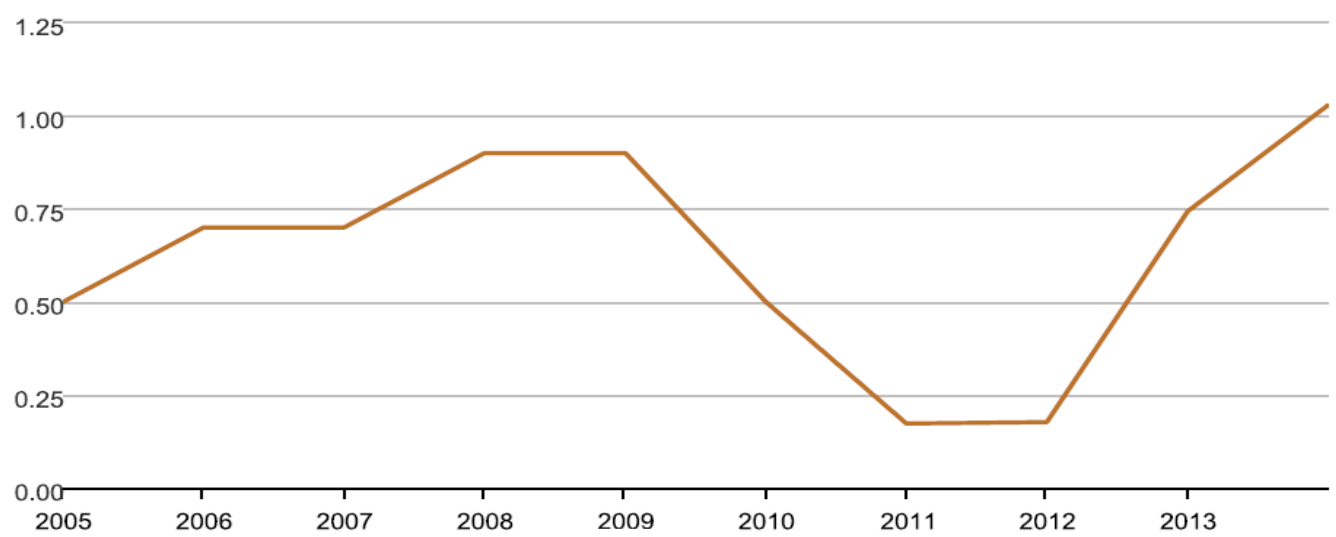

Kaynak: EIA (2017).

Şekil 4'e göre Türkiye'nin biyoetanol üretim düzeyi 2005-2013 döneminde dalgalı bir seyir izlemiştir. 2005 'deki günlük 0,5 bin varil düzeyinden 2006 'da günlük 0,7 bin varil düzeyine yükselmiş, 2006-2007 döneminde sabit kalmış, 2007-2008 döneminde ise yeniden artış göstermiş günlük 0,9 bin varil düzeyine ulaşmıştır. 2008-2009 döneminde sabit kalan biyoetanol üretimi 2009-2011 döneminde keskin bir düşüş yaşayarak günlük 0,17 bin varil düzeyine gerilemiştir. 2011-2012 döneminde sabit kalan Türkiye'nin biyoetanol üretimi 2012 sonrasında yeniden yükseliş trendine girmiştir. 
Biyodizel, kanola, ayçiçeği, vb. yağlı tohum bitkilerinden elde edilen yağların reaksiyonu sonucu üretilen bir enerji yakıtıdır (Horuz vd., 2015: 76). Biyodizel kelimesinin "biyo" kısmı biyolojik esaslı olduğunu, "dizel” kısmı ise dizel bir yakıt olduğunu işaret etmektedir (Alptekin ve Çanakçı, 2006: 58). Biyodizelin bazı yararlarını aşağıdaki biçimde sıralamak mümkündür (Tunalığlu ve Afacan, 2007: 13):

- Tarım sektörünü güçlendirir ve kırsal kesimden göçü azaltır.

- Tarımsal üretimde yarattığı çeşitlilik yoluyla ekoloji üzerind pozitif etkiler oluşturur.

- Tarımsal üretimde sürdürülebilirliğin oluşmasına ve organik tarımın gelişmesine katkıda bulunur.

- Tarımsal üretimde en önemli maliyet kalemi olan enerji ihtiyacının üreticiler tarafından karşılanmasını sağlar.

Biyodizel, saf olarak ya da farklı oranlarda petrol kökenli dizel yakıt ile karıştırılması yoluyla yakıt olarak kullanılabilmektedir (Sabancı vd., 2010: 6). Biyodizel türlerini motorin katk1 maddesi (B1,B2,B5), motorin ile harmanlanarak (B20, B50, B80, vb.) ve doğrudan motor biyoyakıtı (B100) biçiminde ifade etmek mümkündür (Karaosmanoğlu, 2006: 119).

Tablo 13: Kıtalara göre BiyodizelÜretimi (Milyar Litre cinsinden)

\begin{tabular}{|l|c|c|c|c|c|c|}
\hline & Dünya & Afrika & Amerika & Asya & Avrupa & Okyanusya \\
\hline 2000 & 0,84 & 0,00 & 0,02 & 0,00 & 0,81 & 0,00 \\
\hline 2005 & 3,67 & 0,00 & 0,36 & 0,07 & 3,23 & 0,00 \\
\hline 2010 & 20,20 & 0,00 & 6,16 & 2,57 & 11,40 & 0,07 \\
\hline 2011 & 23,30 & 0,00 & 8,76 & 3,47 & 11,00 & 0,10 \\
\hline 2012 & 25,30 & 0,00 & 8,84 & 4,61 & 11,80 & 0,09 \\
\hline 2013 & 28,90 & 0,00 & 11,00 & 5,22 & 12,50 & 0,09 \\
\hline
\end{tabular}

Kaynak: WBA (2016: 53).

Tablo 13'e göre dünya biyodizel üretimi 2000-2013 döneminde \%3340,47 oranında artış göstererek 2000'deki 0,84 milyar litre düzeyinden 2013'de 28,90 milyar litre düzeyine ulaşmıştır. 2000-20013 döneminde biyodizel üretimi, Amerika'da \%54900 oranında ve Avrupa'da \%1443,20 oranında artış göstermiştir. Afrika'da dönemin tamamında biyodizel üretimi söz konusu değil iken Okyanusya'da ise biyoetanol üretimine 2005 sonrasında 
başlanmıştır. 2013 y1lı verilerine göre biyodizel üretiminde Avrupa lider olmakla birlikte, Avrupa'yı sırasıyla Amerika, Asya, Okyanusya ve Afrika takip etmektedir. 2015 yılı verilerine göre biyodizel üretimi bağlamında lider ABD’yi sırasıyla, Brezilya, Almanya, Fransa, Arjantin, Endonezya, Hollanda, Tayland, Singapur ve Malezya takip etmektedir (WBA, 2016: 54).

\section{Şekil 5: Türkiye'nin Biyodizel üretimi (Günlük Bin Varil Cinsinden)}

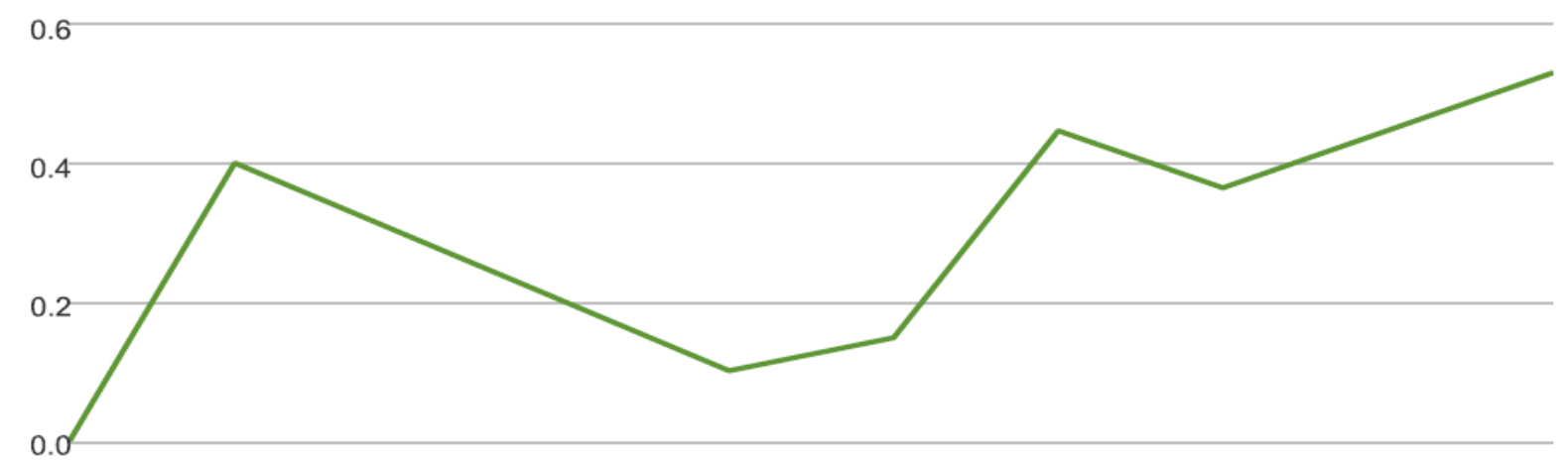

$\begin{array}{cccccccc}-0.2 & 1 & 1 & 1 & 1 & 1 & 1 & 1 \\ 2005 & 2006 & 2007 & 2008 & 2009 & 2010 & 2011 & 2012\end{array}$

Kaynak: EIA (2017)

Şekil 5'e göre Türkiye'nin biyodizel üretim düzeyi 2005-2013 döneminde dalgalı bir seyir izlemiştir. 2005'de Türkiye'de biyodizel üretimi söz konusu değilken, 2006'da biyodizel üretimi günlük 0,4 bin varil düzeyinde gerçekleşmiştir. Biyodizel üretimi 2006-2009 döneminde keskin bir düşüş yaşayarak günlük 0,4 bin varil düzeyinden günlük 0,1 bin varil düzeyine gerilemiştir. Biyodizel üretimi 2009-2011 döneminde ise artış kaydederek günlük 0,1 bin varil düzeyinden günlük 0,45 bin varil düzeyine ulaşmıştır. 2011-2012 döneminde düşüş yaşayarak 2012'de günlük 0,36 bin varil düzeyine gerileyen Türkiye'nin biyodizel üretimi 2012 sonrasında yeniden yükseliş trendine girmiştir.

\section{Biyoyakıtlara İlişkin Politikalar ve Uygulamalar}

ABD, Brezilya, Çin, Hindistan ve Avrupa Birliği’nin biyoyakıtlara ilişkin politikaları ve uygulamaları uluslararası biyoyakıt piyasalarının işleyişinde önemli rol oynamaktadır. 
Buradan hareketle, bu bölümde söz konusu ülkelerde ve Türkiye'de biyoyakıtlara ilişkin politikalara ve uygulamalara yer verilmektedir.

\subsection{ABD}

1978 yılında yürürlüğe giren ve akaryakıta etanol karıştırılması için teşvik getiren Enerji Vergi Yasası ve 1980 yılındaki küçük etanol üreticilerine kredi desteği, fiyat garantisi ve federal satın alma anlaşması sağlayan Enerji Güvenliği Yasası sonrasında 1980'lerde biyoetanol üretimi artış göstermiştir. 1990'lı yılların başından itibaren biyoyakıt politikaları önem kazanmaya başlamıştır. ABD'de zorunlu biyoyakıt tüketim miktarları ilk olarak 2005 yılında Enerji Politikası Yasasında yer alan Yenilenebilir Yakıt Standartları (RFS1) ile uygulanmaya başlamış, 2007 yılında yayımlanan Enerji Bağımsızlığı ve Güvenliği Yasası ile RFS programı birçok konuda genişletilmiş ve Yenilenebilir Enerji Standardı (RFS2) 2010 yılında son halini almıştır. Bu standart, biyoyakıt hedeflerini artırmakta, ikinci nesil biyoyakıtları teşvik etmekte ve çevresel olarak daha sürdürülebilir bir üretimi desteklemektedir (Dağdelen, 2015: 23-24).

\subsection{Brezilya}

Brezilya'da "Ulusal Biyoetanol Programı" 1975 yılında uygulanmaya konmuştur. “Milli” bir enerji kaynağı olarak biyoetanolün geliştirilmesine yönelik çalışmalara, gerçek anlamda sivil yönetime tekrar geçildikten sonra 1990'lı yıllarda başlanmıştır. 2000'li yılların başlarında biyoetanol, sanayide özellikte otomotiv sektöründe yaygın bir biçimde kullanılmaya başlanmıştır. 2007 yılında ABD ve Brezilya arasında biyoetanol işbirliği konusunda bir memorandum imzalanmıştır. ABD ve Brezilya yetkilileri biyoetanol üretimi standartları saptamayı ve bu doğrultuda uluslararası nitelikte bir komisyon oluşturulmasını kararlaştırmıştır. Ayrıca, Brezilya'nın biyoetanolün sanayide kullanımına ilişkin gelişmiş teknolojisinin ABD’ye ve diğer ülkelere transferi ve biyoetanol üretim kapasitesinin artırılmasına yönelik olarak Brezilya'ya yatırımların artırılması ve mali destek verilmesi öngörülmüştür. Hükümet tarafından belirlenen benzin içerisindeki \%25 oranında biyoetanol karıştırılma zorunluluğu, biyoetanol sektörünü koruma altına almaktadır. Bunun yanı sıra, tarımsal üretim alanları büyük miktarda biyoetanol üretimine kaydırılmış ve biyoetanol ile çalışan "Flex" motorlara sahip araçlar üretilmeye başlanmıştır (Uludüz, 2007). 


\section{3. Çin}

Enerji arz güvenliğine, kırsal kalkınmaya ve çevreye ilişkin problemlere çözüm arayan Çin, biyoyakıt üretim ve tüketimini artıracak politikalar oluşturmuştur. Çin, yağlı tohumlarda ithalatçı konumda olmaları nedeniyle biyoyakıt türleri içerisinde hammadde olarak yağlı tohumları kullanan biyodizel sektörünü desteklememekte, gıda-dışı ürün kaynaklı biyoyakıtları desteklemektedir. Çin hükümeti tarafından 2001 yılında Biyoetanol Teşvik Programı başlatılmış ve bu doğrultuda biyoyakıt üretimi amacıyla yararlanılacak tarımsal hammaddelere sübvansiyonlar, ikinci nesil biyoyakıtların geliştirilmesi amacıyla oluşturulacak projelere hibe ve kredi yardımları, Ar-Ge faaliyetlerine ilişkin düşük faizli kredi destekleri ile birtakım vergi indirimleri ve sübvansiyonları gibi destekler biyoyakıt sektöründe uygulanmaktadır (Dağdelen, 2015: 25).

\subsection{Hindistan}

Hindistan, biyoetanol üretiminde şeker kamışını ve biyodizel üretiminde ise jatrofayı hammadde olarak kullanmaktadır. Hindistan hükümeti tarafından Aralık 2009'ta kabul edilen Ulusal Biyoyakıt Politikasında aşağıdaki hükümler yer almaktadır (ICRISAT, 2012: 2):

- Biyodizel üretiminde gidaya konu olmayan ürünlerin hammadde olarak seçilmesi ve söz konusu hammaddelerin yetiştirilmesinde marjinal arazilerin kullanılması amaçlanmıştır.

- 2017 yılına kadar biyoetanol ve biyodizelin fosil yakıtlarla harmanlanma oranı \%20 olarak amaçlanmıştır.

- Biyoyakıt üretimi amacıyla hammadde yetiştiren çiftçilerin muhtemel gelir kayıplarını bertaraf etmek gayesiyle destekleme taban fiyatı uygulaması yürürlüğe konulmuştur.

- İkinci nesil biyoyakıtlar da yer almak kaydıyla, biyoyakıt üretimine ilişkin teknolojilerin geliştirilmesi, inovasyon ve Ar-Ge'ye yönelik faaliyetlerin gerçekleştirilmesi teşvik edilmiştir. 
- Biyodizel ve biyoetanol sektörlerine bütün dolaylı ve dolaysız vergiler hususunda muafiyet getirilmiştir.

\subsection{Avrupa Birliği}

Avrupa Birliği'nde 2003 yılından itibaren biyoyakıtlara yönelik uygulanan strateji aşağıdaki yedi politika çerçevesinde belirlenmiştir (Gizlenci ve Acar, 2008: 5):

- Biyoyakıt üretimine yönelik sübvansiyonlar: 2006 yılında gerçekleştirilen Biyoyakıt Direktifi Revizyonu ile birlikte vergi muafiyetleri, biyoyakıtlara yönelik ulusal üretim hedeflerinin saptanması, sürdürülebilir üretimin sağlanması, kamunun sağladığı ulaşım hizmetlerinde temiz ve verimli araçlardan yararlanılması

- Çevreye ilişkin faydalar: Biyoyakıtların $\mathrm{CO}_{2}$ emisyon azaltımının hesaplanması, benzin ve motorindeki biyoetanol ve biyodizel limitlerinin saptanması

- Biyoyakıt üretiminin ve dağıtımın geliştirilmesi: Üye ülkelerin biyoyakıtlara yönelik kırsal gelişim politikaları ve uyumluluk alanında teşvik edilmesi

- Biyoyakıt üretiminde hammadde olarak kullanılan tarımsal ürünlerin ekiminin yaygın hale getirilmesi

- Biyoyakıt ticaretinin artırılması

- Gelişmekte olan ülkelerin desteklenmesi: Söz konusu ülkelerin biyoyakıt alanında üretime başlaması ve ulusal biyoyakıt plan ve programlarının yürütülmesi açısından gerekli desteğin verilmesi

- Ar-Ge faaliyetlerinin desteklenmesi: Biyoyakıt sektörünün gelişmesi amacıyla biyoyakıtlara ilişkin teknoloji platformlarınının bir sanayi dalı biçiminde geliştirilmesinin teşvik edilmesi

Almanya, Avrupa Birliği'nde biyoyakıtlar konusunda lider ülke durumundadır. "Yenilenebilir Enerji Kaynaklarına Öncelik Tanıma Yasası", biyoyakıtlar konusunu kapsamaktadır. 2007 yılından başlayarak biyoyakıtlara kademeli vergi uygulanmasına 
başlanmış, biyodizelin çiftçi yakıtı olarak kullanılmasında vergi muafiyeti getirilmiş ve benzin ve motorindeki zorunlu karışım oranlarına kota getirilmiştir (Narin, 2008: 8). Fransa, ulusal düzeyde örgütlenen, biyoyakıt üretimi için gerekli yatırımları geliştiren finansal bir proje olan biyoyakıt üretim programını uygulamaya koymuştur. Ayrıca, vergi indirimleri sayesinde biyoyakıtlar fosil yakıtlara görece daha az maliyetli konumda bulunmaktadır. Bunun yanı sıra, biyoyakıt konusuyla ilgilenen benzin şirketleri, araç üreticileri, profesyoneller, ticari birlikler ve ulusal kar amacı gütmeyen kuruluşlar arasında bir bilgi ağı kurulmuştur (Kulözü, 2005). İtalya, 100 binden fazla kişinin yaşadığı yerleşim yerlerinde belediye araçlarında ve konut 1sınması amacıyla biyodizelin kullanımını teşvik etmektedir. İspanya, vergi teşvikinin yanında ayçiçeği yağı kullanımını da desteklemektedir. İngiltere'de, bölgesel uygulamalar söz konusu olmakta ve bazı bölgelerdeki biyodizel kullanımı vergiden muaf tutulmaktadır. Belçika biyoyakıtın \%100 kullanımına izin vermiş, Finlandiya biyoyakıta 0,025 Euro/litre teşvik uygulamasına geçmiş ve Yunanistan yasayla biyodizele vergi muafiyetini getirmiş ve söz konusu alandaki yatırımlara sürekli teşvikler getirmiştir (ALBİYOBİR, 2017).

\subsection{Türkiye}

Dünyadaki gelişmelere paralel olarak, Türkiye'de biyoyakıtlara ilişkin uygulamalar 2000’li yıllar sonrasında artış kaydetmekle birlikte, biyodizele ilişkin ilk çalışmalar, 1931 yılında gerçekleştirilen Ziraat Kongresi'nde gündeme getirilmiştir. Üretime yönelik ilk uygulama 1934 yılında Atatürk Orman Çiftliği’nde “Bitkisel Yağların Tarım Traktörlerinde Yakıt Olarak Kullanımı” başlığıyla yapılmıştır (Narin, 2008: 10).

Türkiye'de biyoyakıtlara yönelik 2000'li yılların başından yapılan ilk yasal düzenleme 5015 sayılı Petrol Piyasası Kanunu'dur. 20.12.2003 tarih ve 25322 sayılı Resmi Gazetede yayımlanarak yürürlüğe giren söz konusu kanunun 2. Maddesi 7. Fıkrasına göre akaryakıtla harmanlanan ürünler, metil tersiyer bütil eter (MTBE), etanol vb. (yerli tarım ürünlerinden denatüre olarak üretilenler ile biodizel hariç) akaryakıt ile eşdeğer vergiye tâbi olan ve olacak ürünler; 44. Fıkraya göre ulusal marker, akaryakıta rafineri çıkışında veya gümrük girişinde eklenecek katkı olarak ifade edilmiştir. Bunun yanısıra, kanunun 9. Maddesinde yerli tarım ürünlerinden elde edilen ve akaryakıt ile harmanlanan ürünlerin akaryakıt ile eşdeğer vergiye tâbi olmayacakları belirtilmiştir (Petrol Piyasası Kanunu, 2003). 
17.06.2004 tarih ve 25495 sayılı Resmi Gazetede yayımlanarak yürürlüğe giren Petrol Piyasası Lisans Yönetmeliği'nin 4. Maddesinin 5.Fıkrasında akaryakıt türleri; benzin türleri, nafta (hammadde, solvent nafta hariç), gazyağı, jet yakıtı, motorin türleri, fuel-oil türleri ile biyodizel biçiminde ifade edilmiştir. Biyodizel de dahil olmak üzere akaryakıtların piyasa faaliyetleri, lisans düzenlemeleri, Enerji Piyasası Düzenleme Kurumu'na bildirimlere yönelik usul ve esaslar saptanmaktadır (Petrol Piyasası Lisans Yönetmeliği, 2004).

10.09.2004 tarih ve 25579 sayılı Resmi Gazetede yayımlanarak yürürlüğe giren Petrol Piyasasında Uygulanacak Teknik Kriterler Hakkında Yönetmelik, petrol piyasasına ilişkin faaliyetler kapsamındaki tesislerin ve piyasaya sunulan petrol ve madeni yağın düzenlemelere ve standartlara uygunluğuna ilişkin usul ve esasların saptanmasını amaçlamaktadır. Ayrıca, söz konusu yönetmelikte biyodizel akaryakıt ürünleri arasında yer almaktadır (Petrol Piyasasında Uygulanacak Teknik Kriterler Hakkında Yönetmelik, 2004).

21.10.2004 tarih ve 25620 sayılı Resmi Gazetede yayımlanarak yürürlüğe giren Etil Alkolün Piyasaya Arzı Hakkında Tebliğde yakıt biyoetanolü; tarımsal ürünlerin, atık ve kalıntılarının, ormancılık, sanayi ve belediye atıklarının biyolojik olarak parçalanabilen kısımlarından elde edilen ve taşımacılıkta kullanılan yakıt olarak ifade edilmiştir (Etil Alkolün Piyasaya Arzı Hakkında Tebliğ, 2004).

19.04.2005 tarih ve 25791 sayılı Resmi Gazetede yayımlanarak yürürlüğe giren Bitkisel Atık Yağların Kontrolü Yönetmeliği, bitkisel atık yağların oluşumundan bertarafına kadar çevre ve insan sağlığına zarar vermeksizin yönetiminin sağlanması, yönetiminde gerekli teknik ve idari standartların oluşturulması ve buna ilişkin prensip, politika ve programların belirlenmesine ilişkin usul ve esasları düzenlemeyi amaçlamaktadır (Bitkisel Atık Yağların Kontrolü Yönetmeliği, 2005).

22.04.2005 tarih ve 25794 sayılı Resmi Gazetede yayımlanarak yürürlüğe giren 2005/8704 sayılı Bakanlar Kurulu Kararı'na göre, yerli tarım ürünlerinden imal edilmiş biyoetanolün benzinle harmanlanması durumunda; benzinden alınan Özel Tüketim Vergisinin, en fazla \%2 olmak üzere biyoetanol miktarının karışım miktarına oranı kadarki kısmına vergi muafiyeti getirilmiştir (2005/8704 sayılı Bakanlar Kurulu Kararı, 2005). 
18.05.2005 tarih ve 25819 sayılı Resmi Gazetede yayımlanarak yürürlüğe giren Yenilenebilir Enerji Kaynaklarının Elektrik Enerjisi Üretimi Amaçlı Kullanımına İlişkin Kanunu, hidrolik, rüzgâr, güneş, jeotermal, biyokütle, biyogaz, dalga, akıntı enerjisi ve gel-git gibi fosil olmayan enerji kaynakları gibi yenilenebilir enerji kaynaklarının elektrik enerjisi üretimi amaçlı kullanımının yaygınlaştırılması, bu kaynakların güvenilir, ekonomik ve kaliteli biçimde ekonomiye kazandırılması, kaynak çeşitliliğinin artırılması, sera gazı emisyonlarının azaltılması, atıkların değerlendirilmesi, çevrenin korunması ve bu amaçların gerçekleştirilmesinde gereksinim duyulan imalat sektörünün geliştirilmesidir (Yenilenebilir Enerji Kaynaklarının Elektrik Enerjisi Üretimi Amaçlı Kullanımına İlişkin Kanun, 2005).

17.01.2007 tarih ve 5574sayılı Resmi Gazetede yayımlanarak yürürlüğe giren Türk Petrol Kanununda biyodizel akaryakıt türleri arasında yer almıştır. Biyodizel; akaryakıt olarak veya akaryakıt ile harmanlanarak kullanılmak üzere, bitkisel ve hayvansal yağlar veya bitkisel ve hayvansal atık yağlardan elde edilen ürün türevi yağ asiti metil esterleri karışımı, biyoetanol, akaryakıt ile harmanlanmak üzere şekerli, nişastalı bitkilerden, her türlü selülozik kaynaklardan ve biyokütle atık ve artıklarından üretilen denatüre etil alkol olarak ifade edilmiştir. Kalite denetimleri ve harmanlama oranları ile ilgili denetimler Enerji Piyasası Düzenleme Kurumu tarafindan yapılır (Türk Petrol Kanunu, 2007).

02.05.2007 tarih ve 26510sayılı Resmi Gazetede yayımlanarak yürürlüğe giren Enerji Verimliliği Kanunu, enerjinin etkin kullanılması, israfının önlenmesi, enerji maliyetlerinin ekonomi üzerindeki yükünün hafifletilmesi ve çevrenin korunması için enerji kaynaklarının ve enerjinin kullanımında verimliliğin artırılmasını amaçlamaktadır. $\mathrm{Bu}$ kanun ayrıca, biyoyakıtların kullanımının özendirilmesini kapsamaktadır (Enerji Verimliliği Kanunu, 2007).

07.08.2009 tarih ve 27312sayılı Resmi Gazetede yayımlanarak yürürlüğe giren Motorin Türlerine İlişkin Teknik Düzenleme Tebliği (Akaryakıt Seri No: 15) ile birlikte motorin ve kırsal motorin tanımlamaları yapılmıştır. Piyasaya akaryakıt olarak arz edilen veya dolaşımda bulunan motorin türlerinin, Türk Standardları Enstitüsü tarafından hazırlanan "TS 3082 EN 590 Otomotiv Yakıtları-Dizel (Motorin)-Gerekler ve Deney Yöntemleri” standardına uygun olması zorunluluğu belirtilmiştir (Motorin Türlerine İlişkin Teknik Düzenleme Tebliği (Akaryakıt Seri No: 15), 2009). 
27.09.2011 tarih ve 28067sayılı Resmi Gazetede yayımlanarak yürürlüğe giren Motorin Türlerine İlişkin Teknik Düzenleme Tebliğinde Değişiklik Yapılmasına Dair Tebliğ (Akaryakıt Seri No: 22) ile birlikte Motorin Türlerine İlişkin Teknik Düzenleme Tebliğine ek olarak piyasaya akaryakıt olarak arz edilen motorin türlerinin, yerli tarım ürünlerinden üretilmiş yağ asidi metil esteri (YAME) içeriğinin; 1.1.2014 tarihi itibariyle en az \%1, 1.1.2015 tarihi itibariyle en az \%2 ve 1.1.2016 tarihi itibariyle en az \%3 olması zorunluluğu getirilmiştir (Motorin Türlerine İlişkin Teknik Düzenleme Tebliğinde Değişiklik Yapılmasına Dair Tebliğ (Akaryakıt Seri No: 22), 2011).

27.09.2011 tarih ve 28067 sayılı Resmi Gazetede yayımlanarak yürürlüğe giren Benzin Türlerine İlişkin Teknik Düzenleme Tebliğinde Değişiklik Yapılmasına Dair Tebliğg (Akaryakıt Seri No: 23) ile birlikte piyasaya akaryakıt olarak arz edilen benzin türlerinin, yerli tarım ürünlerinden üretilmiş etanol içeriğinin; 1.1.2013 tarihi itibariyle en az \%2 ve 1.1.2014 tarihi itibariyle en az \%3 olması zorunluluğu getirilmiştir(Benzin Türlerine İlişkin Teknik Düzenleme Tebliğinde Değisşiklik Yapılmasına Dair Tebliğ (Akaryakıt Seri No: 23), 2011).

25.02.2012 tarih ve 28215sayılı Resmi Gazetede yayımlanarak yürürlüğe giren Enerji Verimliliği Strateji Belgesi (2012-2023) çerçevesinde biyokütle kaynaklarından elde edilen biyoyakıtların veya sentetik yakıtların ulaşımda kullanımı yaygınlaştırılacaktır. Ayrıca, biyoyakıt ve sentetik yakıtların fosil kaynaklı akaryakıtlar içerisindeki harmanlama oranlarının artırılmasının özendirilmesi amacıyla; gıda sektörünü olumsuz etkilemeyecek şekilde, yerli tarım ürünlerinden üretilen biyoyakıt veya sentetik yakıtların harmanlama oranlarına bağlı olarak Özel Tüketim Vergisi indirimi sağlanması yönünde düzenleme yapılacaktır (Enerji Verimliliği Strateji Belgesi (2012-2023), 2012).

07.07.2012 tarih ve 28346sayılı Resmi Gazetede yayımlanarak yürürlüğe giren Benzin Türlerine Etanol Harmanlanması Hakkında Tebliğ, enerjide dışa bağımlılığın azaltılması, kaynak çeşitliliğinin artırılması, çevre kirliliğinin azaltılması ve Avrupa Birliğinin yenilenebilir enerji politikalarına uyum sağlanması amacıyla hazırlanmış olup benzin türlerine yerli tarım ürünlerinden elde edilen etanol harmanlanmasına ilişkin usul ve esasları kapsamaktadır (Benzin Türlerine Etanol Harmanlanması Hakkında Tebliğ, 2012). 


\section{SONUÇ}

1973 'deki petrol krizi ile birlikte enerji güvenliği ve enerjinin çeşitlendirilmesinin temel hedefler halini alması ve 1990'lu yıllarda fosil enerji kaynaklarının olumsuz etkilerinin anlaşılması rüzgâr, biyokütle vb. sınıflardan oluşan yenilenebilir enerji kaynaklarına yönelik yoğun bir ilgi yaratmıştır. Önemli yenilenebilir enerji kaynakları arasında yer alan biyokütlenin taşıdığı büyük potansiyel, çeşitli sosyal ve ekonomik yararlar nedeniyle gelecekte ülkelerin gelişmesinde önemli rol oynayacağı tahmin edilmektedir.

Yenilenebilir kaynaklardan elde edilen toplam birincil enerji arzı 2000-2013 döneminde 54,9 Eksajul düzeyinden 78,1 Eksajul düzeyine ulaşmıştır. 2013 yılı verilerine göre, yenilenebilir kaynaklardan elde edilen toplam birincil enerji arzının \%43,15'lik kısmının Asya tarafından karşılanmasında \%17,70'lik kısmı karşılayan Çin ve \%10,95'lik kısmı karşılayan Hindistan önemli rol oynamaktadır. Yenilenebilir kaynaklardan elde edilen elektrik üretimi ise 2000-2013 döneminde 2954 Terawatt/saat düzeyinden 5190 Terawatt/saat düzeyine ulaşmıştır. 2013 yılı verilerine göre yenilenebilir kaynaklardan elde edilen elektrik üretiminin \%34,91'lik kısmının Asya tarafından karşılanmasında \%21,73'lük kısmı karşılayan Çin önemli rol oynamaktadır. Türkiye'de yenilenebilir enerjiden üretilen elektrik enerjisi, 2001-2012 döneminde dalgalı bir yapı göstererek 2001'deki 24,152 Terawatt/saat düzeyinden 2012'de 64,367 Terawatt/saat düzeyine ulaşmıştır. Biyokütleden elde edilen dünya toplam birincil enerji arzı 2000-2013 döneminde 42,90 Eksajul düzeyinden 57,70 Eksajul düzeyine ulaşmıştır. 2013 y1lı verilerine göre biyokütleden elde edilen dünya toplam birincil enerji arzının \%44,19'luk kısmını karşılayan Asya'nın lider olmasında Çin ve Hindistan önemli rol oynamaktadır. Biyokütleden elde edilen dünya elektrik üretimi 2000-2013 döneminde 170 Terawatt/saat düzeyinden 462 Terawatt/saat düzeyine ulaşmıştır. 2013 yılı verilerine göre biyokütleden elde edilen elektrik üretiminde Avrupa lider konumundadır.

Dünya biyoyakıt üretimi 2000-2013 döneminde 18 Milyar Litre düzeyinden 118 Milyar Litre düzeyine ulaşmıştır. Dünya toplam biyoyakıt üretiminin \%62,28'lik kısmı biyoetanolden, \%24,49'luk kısmı biyodizelden ve \%13,05'lik kısmı diğer biyoyakıtlardan oluşmaktadır. Dünya biyoetanol üretimi 2000-2013 döneminde 13,20 Milyar Litre düzeyinden 73,50 Milyar Litre düzeyine ulaşmıştır. Dünya biyodizel üretimi 2000-2013 döneminde 0,84 Milyar Litre 
düzeyinden 28,90 Milyar Litre düzeyine ulaşmıştır. Dünya diğer biyoyakıtlar üretimi ise 20002013 döneminde 3,94 Milyar Litre düzeyinden 15,40 Milyar Litre düzeyine ulaşmıştır. Toplam biyoyakıt, biyoetanol ve diğer biyoyakıtlar üretiminde Amerika ve biyodizel üretiminde Avrupa lider konumdadır. Türkiye'nin biyoyakıt üretim düzeyi 2005-2013 döneminde dalgalı bir seyir izlemiştir. 2005'deki günlük 0,5 bin varil düzeyinden 2013'de günlük 1,25 bin varil düzeyini aşar hale gelmiştir. Türkiye'nin biyoetanol üretim düzeyi 2005-2013 döneminde dalgalı bir seyir izlemiştir. 2005 'deki günlük 0,5 bin varil düzeyinden 2013 'de günlük 0,75 bin varil düzeyini aşar hale gelmiştir. Türkiye'nin biyodizel üretim düzeyi 2005-2013 döneminde dalgalı bir seyir izlemiştir. 2005'de Türkiye'de biyodizel üretimi söz konusu değilken 2013'de günlük 0,4 bin varil düzeyini aşar hale gelmiştir.

Biyoyakıtlara ilişkin politikalar ve uygulamalara bakılacak olursa, ABD'de Enerji Vergi Yasası ve Enerji Güvenliği Yasası ile birlikte biyoetanol üretimi artış göstermiş ve biyoyakıt politikaları önem kazanmaya başlamıştır. Yenilenebilir Yakıt Standartları (RFS1) ve Yenilenebilir Enerji Standardı (RFS2) ile birlikte biyoyakıt hedefleri artırılmış, ikinci nesil biyoyakıtlar teşvik edilmiş ve çevresel olarak daha sürdürülebilir bir üretim desteklenmiştir. Brezilya'da, biyoetanolün geliştirilmesine yönelik çalışmalara, gerçek anlamda 1990'lı yıllarda başlanmış ve 2000'li yılların başlarında ise biyoetanol, sanayide özellikte otomotiv sektöründe yaygın bir biçimde kullanılmaya başlanmıştır. Hükümet tarafından belirlenen benzin içerisindeki \%25 oranında biyoetanol karıştırılma zorunluluğu, biyoetanol sektörünü koruma altına alırken tarımsal üretim alanları büyük miktarda biyoetanol üretimine kaydırılmış ve biyoetanol ile çalışan "Flex" motorlara sahip araçlar üretilmeye başlanmıştır. Çin hükümeti tarafindan 2001 yılında Biyoetanol Teşvik Programı başlatılmış olup biyoyakıt üretiminde kullanılacak tarımsal ürünlere sübvansiyonlar, ikinci nesil biyoyakıtların geliştirilmesine ilişkin projelere hibe ve kredi yardımları, Ar-Ge faaliyetlerine yönelik düşük faizli kredi destekleri ile çeşitli vergi indirimleri ve sübvansiyonları gibi destekler biyoyakıt sektöründe uygulanmaktadır. Hindistan hükümeti tarafından Aralık 2009'ta Ulusal Biyoyakıt Politikası kabul edilmiş olup biyodizel üretiminde gıdaya konu olmayan ürünlerin hammadde olarak seçilmesi ve söz konusu hammaddelerin yetiştirilmesinde marjinal arazilerin kullanılması amaçlanmış, biyodizel ve biyoetanol sektörlerinin tüm dolaylı ve dolaysız vergilerden muaf tutulması sağlanmış, biyoyakıt üretimi için hammadde yetiştiren çiftçilerin muhtemel gelir kayıplarının önlenmesi amacıyla destekleme taban fiyatı uygulaması yürürlüğe konulmuş, 
biyoyakıt üretimine yönelik Ar-Ge faaliyetleri teşvik edilmiş ve 2017 yılına kadar biyoetanol ve biyodizelin fosil yakıtlarla harmanlanma oranı \%20 olarak amaçlanmıştır. Avrupa Birliği’nde 2003 yılından itibaren biyoyakıtlara yönelik uygulanan strateji; biyoyakıt üretimine yönelik sübvansiyonlar, çevreye ilişsin faydalar, biyoyakıt üretim ve dağıtımının geliştirilmesi, biyoyakıt üretiminde hammadde olarak kullanılan tarımsal ürünlerin ekiminin yaygın hale getirilmesi, biyoyakıt ticaretinin artırılması, gelişmekte olan ülkelerin desteklenmesi ve Ar-Ge faaliyetlerinin desteklenmesi biçimindeki yedi politika çerçevesinde belirlenmiştir.

Türkiye'de biyoyakıtlara ilişkin uygulamalar 2000'li yıllar sonrasında artış kaydetmiş olup çeşitli kanun, yönetmelik ve tebliğler ile birlikte biyoyakıtların yasal altyapısı oluşturulmuş, enerji üretim ve kullanımında biyoyakıtların kullanımı desteklenmiş ve biyoyakıtların ulaşımda kullanımının yaygınlaştırılması hedeflenmiştir. Diğer taraftan, söz konusu gelişmelere karşın Türkiye'de biyokütle enerjisi ve biyoyakıtların üretimi istenilen düzeyde değildir. Bu bağlamda, biyoyakıt sektörü için gerekli tarımsal hammaddeler olan yağlı bitkisel tohumlar açısından avantajlı durumda olan Türkiye'nin biyoyakıt üretim stratejisi yerli tarımsal üretime dayalı olmalıdır. Hakim olan klasik biyokütle enerji kaynaklarının yerini modern biyokütle enerji kaynaklarının almasını sağlayacak girişimlerde bulunulmalıdır. ABD'de mısır ve Brezilya'da şeker kamışının ülkelerin özelliklerine göre biyoetanol üretiminde kullanılan tarımsal hammaddeler olarak seçilmesi gibi Türkiye'de de tarımsal bir hammaddede karar kılınarak biyoyakıt üretiminin söz konusu hammadde etrafinda şekillendirilmesi gerekmektedir. Tarımsal üreticinin sosyoekonomik düzeyinin artırılmasında biyoyakıtların ayrı bir sektör oluşturacağının farkına varılmalı ve Hindistan örneğinde olduğu gibi biyoyakıt üretiminde kullanılan tarımsal hammaddeyi yetiştiren üreticilerin muhtemel gelir kayıplarının önlenmesi amacıyla destekleme taban fiyatı vb. uygulamalar yürürlüğe konulmalıdir.

\section{KAYNAKÇA}

Akdoğan, G. ve Emeklier, H. Y. (2007). Türkiye Tarımında Biyokütle (Biyomas) Enerji Kaynakları, Biyoyakıtlar ve Biyoyakıt Teknolojileri Sempozyumu Bildiriler Kitabı, 1213 Aralık 2007, Ankara, 31-47. (Çevrimiçi erişim tarihi 16.01.2017, http://www.kmo.org.tr/resimler/ekler/d0eb8efbc17cf50_ek.pdf) 
Alptekin, E. ve Çanakçı, M. (2006). Biyodizel ve Türkiye'deki Durumu, Mühendis ve Makina, 47(561), 57-64.

ALBIYOBİR (Alternatif Enerji ve Biyodizel Üreticileri Birliği) (2017). AB Ülkelerinde Biyodizel. (Çevrimiçi $\quad$ erişim tarihi http://www.albiyobir.org.tr/dunyada_b2.htm)

BAKA (Batı Akdeniz Kalkınma Ajansı) (2012). Biyokütle Sektör Raporu. (Çevrimiçi erişim tarihi 17.01.2017,https://www.baka.org.tr/uploads/1349952570BiYOKUTLESEKTOR-RAPORU-11EYLUL.pdf)

Benzin Türlerine Etanol Harmanlanması Hakkında Tebliğ (2012). (Çevrimiçi erişim tarihi 18.01.2017, http://www.resmigazete.gov.tr/eskiler/2012/07/20120707-35.htm)

Benzin Türlerine İlişkin Teknik Düzenleme Tebliğinde Değişiklik Yapılmasına Dair Tebliğ (Akaryakıt Seri No: 23) (2011). (Çevrimiçi erişim tarihi 17.01.2017, http://www.resmigazete.gov.tr/eskiler/2011/09/20110927-5.htm)

Bitkisel Atık Yağların Kontrolü Yönetmeliği (2005). (Çevrimiçi erişim tarihi 16.01.2017,http://www.resmigazete.gov.tr/eskiler/2015/06/20150606-5.htm)

Dağdelen, D. (2015). Küresel Biyoyakıt Politikalarının AB ve Türkiye Açısından Değerlendirilmesi, T.C Gıda, Tarım ve Hayvancılık Bakanlığı Avrupa Birliği ve Dış İlişkiler Genel Müdürlüğü AB Uzmanlık Tezi. (Çevrimiçi erişim tarihi 17.01.2017, http://www.tarim.gov.tr/ABDGM/Belgeler/\%C4\%B0DAR\%C4\%B0\%20\%C4\%B0\% C5\%9ELER/Uzmanlik\%20Tez\%20may\%C4\%B1s\%202015/Derya\%20Dagdelen.pdf)

EIA (U.S. Energy Information Administration), (2017). (Çevrimiçi erişim tarihi 16.01.2017, http://www.eia.gov/beta/international/data/browser/\#/?pa=0000000000000000000000 00000001im\&tl_id=2-A\&vs=INTL.29-12-AFRC-

$\underline{B K W H} . A \& v o=0 \& v=H \&$ start $=1980 \&$ end $=2014$ )

Enerji Verimliliği Kanunu (2007). (Çevrimiçi erişim tarihi 17.01.2017,http://www.resmigazete.gov.tr/eskiler/2007/05/20070502-2.htm) 
Enerji Verimliliği Strateji Belgesi (2012-2023) (2012). (Çevrimiçi erişim tarihi 18.01.2017, http://www.resmigazete.gov.tr/eskiler/2012/02/20120225-7.htm)

Etil Alkolün Piyasaya Arzı Hakkında Tebliğ (2004).(Çevrimiçi erişim tarihi 16.01.2017,http://www.ieis.org.tr/ieis/tr/legislation/18/diger)

Gizlenci, Ş. ve Acar, M. (2008). Enerji Bitkileri Tarımı ve Biyoyakıtlar (Biyomotorin, Biyoetanol, Biyomas), T.C. Tarım ve Köyişleri Bakanlı̆̆ı Tarımsal Araştırmalar Genel Müdürlüğü Karadeniz Tarımsal Araştırma Enstitüsü Müdürlüğü Enerji Bitkileri ve BiyoyakutlarSektörel Rapor. (Çevrimiçi erişim tarihi 17.01.2017, http://arastirma.tarim.gov.tr/ktae/Belgeler/brosurler/Enerji\%20Tar\%C4\%B1m\%C4\%B 1\%20ve\%20Biyoyak\%C4\%B1tlar\%20Sekt\%C3\%B6rel\%20Raporu.pdf)

Hatunoğlu, E. E. (2010). Biyoyakıt Politikalarının Tarım Sektörüne Etkileri, DPT Uzmanlık $\begin{array}{lllll}\text { Tezleri. } & \text { (Çevrimiçi } & \text { erişim } & \text { tarihi }\end{array}$ http://www.surdurulebilirkalkinma.gov.tr/wpcontent/uploads/2016/06/Biyoyakit_Politikalarinin_Tarim_Sektorune_Etkileri.pdf)

Horuz, A., Korkmaz, A. ve Akınoğlu, G. (2015). Biyoyakıt Bitkileri ve Teknolojisi, Toprak Bilimi ve Bitki Besleme Dergisi, 3(2), 69-81.

ICRISAT (International CropsResearchInstituteforthe Semi-AridTopics) (2012). A Review of theNationalBiofuelPolicy in India: A critique of theNeedtoPromoteAlternativeFeedstocks, WorkingPaper Series no.34. (Çevrimiçi erişim tarihi 17.01.2017, http://oar.icrisat.org/6520/1/WPS_34.pdf)

Karaosmanoğlu, F. (2006). Biyoyakıt teknolojisi ve İTÜ araştırmaları, ENKÜS 2006: ITÜ Enerji Çalıştayı ve Sergisi Bildiriler ve Sunumlar, Enerji Enstitüsü Yayınlarl, No:2006/1, 110-146. (Çevrimiçi erişim tarihi 18.01.2017, http://www.iaea.org/inis/collection/NCLCollectionStore/_Public/41/103/41103125.pdf \#page $=120$ ) 
Kulözü, N. (2005). Yenilenebilir Enerji Politikaları: Fransa Örneği, TMMOB Elektrik Mühendisleri Odası (EMO), III. Yenilenebilir Enerji Kaynakları Sempozyumu ve Sergisi Bildirileri, 19-21 Ekim 2005, Mersin. (Çevrimiçi erişim tarihi 17.01. 2017, http://www.emo.org.tr/ekler/a37abdeefe1dab1_ek.pdf)

Motorin Türlerine İlişkin Teknik Düzenleme Tebliği (Akaryakıt Seri No: 15) (2009). $\begin{array}{llll}\text { (Çevrimiçi } \quad \text { tarihi } & \text { 16.01.2017, }\end{array}$ http://www.resmigazete.gov.tr/eskiler/2009/08/20090807-7.htm)

Motorin Türlerine İlişkin Teknik Düzenleme Tebliğinde Değişiklik Yapılmasına Dair Tebliğ (Akaryakıt Seri No: 22) (2011). (Çevrimiçi erişim tarihi 18.01.2017, http://www.resmigazete.gov.tr/eskiler/2011/09/20110927-4.htm)

Narin, M. (2008). Dünya'da ve Türkiye'de Enerji Tarımı, 2. Ulusal İktisat Kongresi DEÜ IIIBF İktisat Bölümü, 20-22 Şubat 2008, İzmir. (Çevrimiçi erişim tarihi 16.01. 2017, http://debis.deu.edu.tr/userweb/iibf_kongre/dosyalar/narin.pdf)

Öztürk, H. H. ve Ekinci, K. (2016). Türkiye'de Biyokütleden Elektrik Üretimi: Mevcut Durum ve Beklentiler, 2. Ulusal Biyoyakıtlar Sempozyumu Bildiriler Kitabı, 27-30 Eylül 2016, Samsun, 17-26. (Çevrimiçi erişim tarihi18.01.2017, http://www.biyoyakit2016.org/bildirler_kitabi.pdf)

Petrol Piyasası Kanunu (2003).(Çevrimiçi erişim tarihi 18.01.2017, http://www.resmigazete.gov.tr/eskiler/2003/12/20031220.htm)

Petrol Piyasası Lisans Yönetmeliği (2004). (Çevrimiçi erişim tarihi 17.01.2017, http://mevzuat.basbakanlik.gov.tr/Metin.Aspx?MevzuatKod=7.5.5719\&MevzuatIliski $=0 \&$ sourceXmlSearch)

Petrol Piyasasında Uygulanacak Teknik Kriterler Hakkında Yönetmelik (2004). (Çevrimiçi erișim tarihi 16.01.2017, http://www.mevzuat.gov.tr/Metin.Aspx?MevzuatKod=7.5.5721\&sourceXmlSearch=\& $\underline{\text { MevzuatIliski=0) }}$ 
Sabanc1, A., Ören, M. N., Yaşar, B., Öztürk, H. H. ve Atal, M. (2010). Türkiye'de Biyodizel ve Biyoetanol Üretiminin Tarım Sektörü Açısından Değerlendirilmesi, Ziraat Mühendisliği VII. Teknik Kongresi Bildiriler Kitabı, 11-15 Ocak 2010, Ankara, 1-19. $\begin{array}{lll}\text { (Çevrimiçi erişim tarihi: } & \text { 17.01.2017, }\end{array}$ http://www.zmo.org.tr/resimler/ekler/cf0ed8641cfcbbf_ek.pdf)

Tunalıoğlu, R. ve Afacan, T. (2007). Türkiye'de Biyodizel Politikaları ve Mevcut Kurumsal Yapının Değerlendirilmesi, Biyoyakıtlar ve Biyoyakıt Teknolojileri Sempozyumu Bildiriler Kitabı, 12-13 Aralık 2007, Ankara, 11-19. (Çevrimiçi erişim tarihi 16.01.2017,http://www.kmo.org.tr/resimler/ekler/d0eb8efbc17cf50_ek.pdf)

Türk Petrol Kanunu (2007). (Çevrimiçi erişim tarihi 17.01.2017, https://www.tbmm.gov.tr/tutanaklar/KANUNLAR_KARARLAR/kanuntbmmc091/ka nuntbmmc091/kanuntbmmc09105574.pdf)

Uludüz, Ö. (2007). Biyo-yakıtlar: Brezilya Örneği, Dışişleri Bakanlığı Yayınları Uluslararası Ekonomik Sorunlar Dergisi, 26. (Çevrimiçi erişim tarihi 17.01.2017,http://www.mfa.gov.tr/biyo-yakitlar_brezilya-ornegi-.tr.mfa)

WBA (World Bioenergy Association) (2016). WBA Global Bionergy Statistics 2016. $\begin{array}{lll}\text { (Çevrimiçi erişim tarihi } & \text { 18.01.2017, }\end{array}$ http://www.indiaenvironmentportal.org.in/files/file/WBA\%20GBS\%202016.pdf)

Yenilenebilir Enerji Kaynaklarının Elektrik Enerjisi Üretimi Amaçlı Kullanımına İlişkin Kanun (2005). (Çevrimiçi erişim tarihi http://www.resmigazete.gov.tr/eskiler/2005/05/20050518-1.htm)

Yılmaz, M. (2012). Türkiye'nin Enerji Potansiyeli ve Yenilenebilir Enerji Kaynaklarının Elektrik Enerjisi Üretimi Açısından Önemi, Ankara Üniversitesi Çevrebilimleri Dergisi, $4(2), 33-54$.

2005/8704 sayılı Bakanlar Kurulu Kararı (2005).(Çevrimiçi erişim tarihi 18.01.2017,http://www.resmigazete.gov.tr/eskiler/2005/08/20050809-16.htm) 